\title{
The Relationship Between Vitamin D Deficiency and Restless Legs Syndrome in Pregnancy
}

\section{Gebelikte D Vitamini Eksikliği ve Huzursuz Bacaklar Sendromu Ilișskisi}

\author{
(D) Gonca Sağlam, (D) Gizem Pektaş* , (1) Serdar Karakullukçu** , (D) Bedri Aras Pektaş*, (D) Demet Sağlam Aykut*** \\ Erzurum Regional Training and Research Hospital, Clinic of Physical Therapy and Rehabilitation Erzurum, Turkey \\ ${ }^{*}$ Kaş State Hospital, Clinic of Obstetrics and Gynecology, Antalya, Turkey \\ **Bayburt Community Health Center, Bayburt, Turkey \\ ***Karadeniz Technical University, Department of Psychiatry, Trabzon, Turkey
}

\begin{abstract}
Objective: Restless Legs syndrome is a common sleep-related movement disorder, and vitamin D deficiency is claimed to play a role in the emergence of the disease. This study aimed to evaluate the relationship between vitamin $D$ deficiency and the prevalence and severity of Restless Legs syndrome, as well as assess the effects of Restless Legs syndrome on sleep quality during pregnancy.

Materials and Methods: Overall, 145 pregnant women were enrolled in the study. Participants were divided into the following two groups based on serum $25(\mathrm{OH})$ vitamin D levels: low $(<20 \mathrm{ng} / \mathrm{mL})$ and normal $(\geq 20 \mathrm{ng} / \mathrm{mL}$ ). The pregnant women were screened for Restless Legs syndrome by using the diagnostic criteria of the International Restless Leg Syndrome Study Group Rating scale. Pittsburg Sleep Quality index was used to evaluate sleep quality. The groups were compared statistically.

Results: Overall, $58.2 \%$ of patients in the vitamin D deficient group and $27.7 \%$ in the vitamin D sufficient group were diagnosed with Restless Legs syndrome. Notably, Restless Legs syndrome severity and Pittsburg scores were significantly higher in patients with low vitamin D levels. Conclusion: To our knowledge, this is the first study to address the link between vitamin $D$ deficiency and the frequency and symptom severity of Restless Legs syndrome in pregnant women. The findings of this study indicate the need to evaluate vitamin $D$ deficiency in pregnant women with restless legs symptoms.
\end{abstract}

Keywords: Pregnancy, Restless Legs syndrome, vitamin D, sleep quality
Öz

Amaç: Huzursuz Bacaklar sendromu sık görülen, uyku ile ilişkili bir hareket bozukluğu olup hastalığın ortaya çıkışında D vitamini eksikliğinin rolü vardır. Bu çalışmanın amacı gebelerde vitamin D eksikliği ile Huzursuz Bacaklar sendromunun prevalansı ve şiddeti arasındaki ilişkiye değerlendirmek ve Huzursuz Bacaklar sendromunun uyku üzerine etkisini belirlemektir.

Gereç ve Yöntem: Yüz kırk beş gebe kadın çalışmaya dahil edildi. Katılımcılar vitamin D düzeyi düşük olanlar $(<20 \mathrm{ng} / \mathrm{mL})$ ve normal olanlar ( $\geq 20 \mathrm{ng} / \mathrm{mL}$ ) olmak üzere iki gruba ayrıldı. Uluslararası Huzursuz Bacaklar Sendromu Çalışma Grubu ve Uluslararası Değerlendirme ölçeğine göre gebeler Huzursuz Bacaklar sendromu açısından incelendi. Uyku kalitesini ölçmek için Pitssburg Uyku Kalitesi indeksi kullanıldı. Gruplar istatistiksel olarak karşılaştırıldı.

Bulgular: Huzursuz Bacaklar sendromu tanısı D vitamini eksikliği olan grupta \%58,2, D vitamini yeterli grupta \%27,7 olarak belirlendi. Düşük vitamin D düzeyleri olan hastalarda Huzursuz Bacaklar sendromu şiddeti ve Pitssburg skorları anlamlı olarak daha yüksekti.

Sonuç: Bildiğimiz kadarıyla, bu çalışma gebe kadınlarda D vitamini eksikliği ile Huzursuz Bacaklar sendromunun sıklığı ve semptom şiddeti arasındaki bağlantıyı ele alan ilk çalışmadır. Bu çalışmanın bulguları, huzursuz bacak semptomları olan gebe kadınlarda D vitamini eksikliği değerlendirmesinin gerekliliğini gösterebilir.

Anahtar Kelimeler: Gebelik, Huzursuz Bacaklar sendromu, D vitamini, uyku kalitesi

\section{Introduction}

Restless Legs syndrome (RLS) is a chronic, progressive movement disorder characterized by an irresistible urge to move the legs accompanied by the abnormal sensations. Two forms of this disorder are identified. Primary disease is idiopathic, secondary form is accompanied by various conditions like pregnancy, iron deficiency, end-stage renal disease or neuropathy. Both forms have the same symptoms and diagnostic criteria (1). RLS is 2-3 times more common in pregnancy than general population which is considered as a major cause for secondary RLS (2).

Address for Correspondence/Yazışma Adresi: Gonca Sağlam MD, Erzurum Regional Training and Research Hospital, Clinic of Physical Therapy and Rehabilitation Erzurum, Turkey Phone: +90 5054525688 E-mail: goncasaglam@hotmail.com ORCID-ID: orcid.org/0000-0001-7713-4435 Received/Geliş Tarihi: 22.12.2019 Accepted/Kabul Tarihi: 07.05.2020

${ }^{\circ}$ Copyright 2020 by Turkish Sleep Medicine Society / Journal of Turkish Sleep Medicine published by Galenos Publishing House. 
According to prevelance studies, a sizeable number of pregnant women were found to be suffering from RLS (10-34\%) and it is the most common movement disorder in pregnancy, peaks in the third trimester. Severity of RLS and sleep disturbance caused by RLS are also more prominent in the last trimester (3-6). Prior reports suggest that the age, number of previous pregnancies, hormonal factors (prolactin, progesterone, estrogens), psychomotor/behavioral factors, genetic predisposition, anxiety and metabolic factors (decreased folate and iron levels) may be the most important risk factors for development of RLS in pregnant women. A few studies also demonstrated that vitamin D deficiency is also associated with RLS in adults (7-9).

Vitamin $D$ is essential for the appropriate neuronal function and dopaminergic neurotransmission (10), this neural mechanism explains the development of RLS in vitamin D deficiency. The existing data also indicates that RLS is linked to an increased incidence of sleep deprivation leading to adverse outcomes, preeclampsia, birth complications and depressed mood (11-15). The diagnosis of RLS is based on clinical symptoms. International RLS Study Group (IRLSSG) has modified the diagnostic criteria for RLS in 2011, suggesting five key criteria which should all be present $(16,17)$.

RLS is commonly associated with pregnancy and the symptoms impact sleep and life quality negatively (4). In this study, we aimed to assess the relationship between vitamin D deficiency and the prevalance and severity of RLS and to evaluate the effect of RLS on sleep quality.

\section{Materials and Methods}

This cross-sectional study was conducted in an obstetrics clinic to evaluate the presence of RLS in pregnant women. A total number of 145 women who attented to an obstetric clinic for routine exam for pregnancy in each trimester was enrolled into this study. The inclusion criteria were: being 18 years or older without radiculopathy, plexopathy, polyneuropathy, peripheral nerve lesions and vascular diseases. Epidemiological and clinical data of the patients such as age, pregnancy week, comorbid diseases, smoking status and laboratory parameters including serum 25-hydroxy $(\mathrm{OH})$ vitamin $\mathrm{D}$, calcium, ferritin, and thyroid function tests were recorded. An obstetrician interviewed all the participants and collected social and labaratory data while another obstetrician consulted patients to a neurologist and the patients were evaluated according to IRLSSG diagnostic criteria. The diagnosis of RLS was made if the patients were met all of the following criteria: 1) the urge to move the legs usually accompanied or caused by uncomfortable, unpleasant sensations in the legs, 2) symptoms begin or worsen during rest or inactivity, 3) worsening symptoms with rest, relief of the symptoms on movement of the limbs, return of symptoms on cessation of the movements, 4) symptoms only occur or are worse in the evening or night than during the day, 5) the occurrence of these features are not accounted for as symptoms primary to another medical condition $(16,17)$.

Pittsburg Sleep Quality index (PSQI) was used to determine sleep quality. The participants that diagnosed with RLS were also screened by IRLSSG Disease Severity scale. Patients were divided into two groups: patients with low $25(\mathrm{OH})$ vitamin $\mathrm{D}(<20 \mathrm{ng} / \mathrm{mL})(\mathrm{n}=98)$ (group 1$)$ and normal $25(\mathrm{OH})$ vitamin D levels $(\geq 20 \mathrm{ng} / \mathrm{mL}) \quad(\mathrm{n}=47)$ (group 2). We state that this study was approved by an ethics committee (2017/143) and informed consent was obtained from all study participants.

\section{IRLSSG Disease Severity Scale}

The Disease Severity scale developed by IRLSSC consists of 10 questions. Each questions are rated between $0-4$, none to very severe. The first 5 questions address the severity of symptoms and the last 5 questions were directed to the effects of RLS on daily life activities. The total score reflects the severity of the disease. The maximum score is 40 and the scale is graded as 1-10 mild, $11-20$ moderate, $21-30$ severe, and 31-40 very severe symptoms.

\section{Pitssburgh Sleep Quality Index}

The Pittsburgh Sleep Quality Index is an effective instrument which is widely used to determine the quality of sleep over a

\begin{tabular}{|c|c|c|c|}
\hline & $\begin{array}{l}\text { Group } 1(n=98) \\
\mathrm{N} \%\end{array}$ & $\begin{array}{l}\text { Group } 2(n=47) \\
\mathrm{N} \%\end{array}$ & \multirow[t]{2}{*}{$p$} \\
\hline & $($ Mean \pm SD) & $($ Mean \pm SD) & \\
\hline Age & $27.0 \pm 6.1$ & $28.1 \pm 5.1$ & 0.248 \\
\hline Number of previous pregnancies & $1.8 \pm 1.0$ & $1.6 \pm 0.9$ & 0.238 \\
\hline Gestational week & $27.0 \pm 10.9$ & $27.6 \pm 6.9$ & 0.504 \\
\hline Pre-pregnancy smoking history & $8.1 \%(n=8)$ & $10.6 \%(n=5)$ & 0.757 \\
\hline Hemoglobin $(\mathrm{g} / \mathrm{dL})$ & $11.5 \pm 1.4$ & $11.7 \pm 1.1$ & 0.544 \\
\hline Ferritin $(\mathrm{ng} / \mathrm{mL})$ & $25.2 \pm 8.8$ & $26.6 \pm 7.5$ & 0.097 \\
\hline $\mathrm{T} 4$ (ng/dL) & $1.2 \pm 0.5$ & $1.2 \pm 0.3$ & 0.450 \\
\hline $\mathrm{TSH}(\mu \mathrm{IU} / \mathrm{I})$ & $2.2 \pm 2.1$ & $2.2 \pm 1.4$ & 0.436 \\
\hline Calcium (mg/dL) & $8.8 \pm 0.5$ & $9.0 \pm 0.7$ & 0.132 \\
\hline IRLSSG Rating Scale score $(n=70)$ & $17.5 \pm 7.2$ & $11.1 \pm 6.5$ & 0.007 \\
\hline Total score of PSQI & $6.6 \pm 5.0$ & $3.3 \pm 3.7$ & $<0.001$ \\
\hline
\end{tabular}


1-month time interval. It measures seven domains: subjective sleep quality, sleep latency, sleep duration, habitual sleep efficiency, sleep disturbances, use of sleep medication and daytime dysfunction. A cutoff score of 5 discriminates between those with "good" and "poor" sleep (18).

\section{Statistical Analysis}

Data were analyzed by the SPSS 23.0 statistics program. In comparisons between groups, Mann-Whitney $U$ test was used for continuous variables, the chi-square test was used for categorical variables and the correlation analysis was done by the Spearman's test. A probability level below 0.05 was considered as statistically significant.

\section{Results}

There were 98 participants in group 1 and 47 participants in group 2. There was no considerable difference between two groups regarding age, number of previous pregnancies, gestational week, pre-pregnancy smoking history and concomitant diseases between two groups. Serum hemoglobin, ferritin, tyroxin and calcium levels were found to be similar in both groups ( $p>0.05)$. Table 1 shows the data of parameters of the groups with low and normal serum $25(\mathrm{OH})$ vitamin D levels.

Diagnosis for RLS was made in 57 (58.2\%) out of 98 in vitamin D deficient group (group 1) and 13 (27.7\%) out of 47 in vitamin D sufficient group (group 2) (Table 2). The mean IRLSSG severity score for group 1 was $17.5 \pm 7.2$ in group 1, while it was $11.1 \pm 6.5$ in group 2 .

RLS severity according to IRLSSG rating scale was significantly higher in group $1(p=0.001)$ (Table 3$)$. RLS was graded as severe to very severe in $25.2 \%$ of group 1 . The mean PSQI was significantly higher in group 1 indicating poor sleep $(p<0.001)$. $62.2 \%(n=61)$ of group 1 had high PSQI , this rate was $14.9 \%$ $(n=7)$ in group 2. The mean PSQI score was $6.6 \pm 5.0$ in group 1 and $3.3 \pm 3.7$ in group 2 (Table 2 ).
The correlation between total PSQI scores and RLS severity scores of pregnant women was also examined and a statistically significant, positive correlation was found $(p<0.001)(r=0.519)$.

\section{Discussion}

RLS is the most common movement disorder of pregnancy but it is neglected despite of the frequent complaints of sleep deterioration in pregnancy. Various factors are thought to contribute to the pathogenesis of RLS in pregnancy, but the underlying mechanism remains unclear. Dietary, hormonal, physiological and genetic factors may be predispositions of RLS formation.

Researchers have indicated that vitamin $D$ increases the levels of dopamine in the brain and protects dopaminergic neurons against several toxins. Vitamin D deficiency may cause an imbalance of dopamine levels. Neuroprotective and immunomodulatory effects of this hormone may be considered in the pathology of neurodegenerative and neuroimmune diseases (19). Vitamin D inhibits nitric oxide synthesis, upregulates enzymes in glutathione and neurotrophin synthesis, regulates neuronal calcium levels, synthesis neurotrophic factors and protects neuronal integrity $(19,20)$. The neural functions of vitamin D in RLS are engrossing. In addition, the role of vitamin $D$ was further substained with increased concentration of vitamin $D$ binding protein in cerebrospinal fluid in patients with RLS. This finding also supports the role of vitamin D in the occurence of RLS (21). On the other hand, RLS patients exhibit an altered dopaminergic profile in the putamen and substantia nigra compared with controls $(20,22-25)$.

Literature suggests that age, number of pregnancies, folate, iron supplementation and ferritin levels are all related with higher prevelance of RLS in pregnancy (3). Although there is convincing evidence for a role of vitamin D in the pathophysiology of RLS in non-pregnant adults, this relationship is not assessed previously and there is insufficient evidence to recommend vitamin $D$ treatment during pregnancy or lactation to prevent RLS (26).

\begin{tabular}{|l|l|l|l|l|}
\hline \multicolumn{5}{|l|}{ Tablo 2. Comparison of Restless Legs syndrome presence and total Pittsburgh Sleep Quality index scores between groups } \\
\hline & $\begin{array}{l}\text { RLS (-) } \\
\mathbf{n}(\%)\end{array}$ & $\begin{array}{l}\text { RLS (+) } \\
\mathbf{n}(\%)\end{array}$ & $\begin{array}{l}\text { PSQI: } \mathbf{0 - 5} \\
\mathbf{n}(\%)\end{array}$ & $\begin{array}{l}\text { PSQI }>5 \\
\mathbf{n}(\%)\end{array}$ \\
\hline Group 1 & $41(41.8)$ & $57(58.2)$ & $37(37.8)$ & $61(62.2)$ \\
\hline Group 2 & $34(72.3)$ & $13(27.7)$ & $40(85.1)$ & $7(14.9)$ \\
\hline Total & $\begin{array}{l}75(86.9) \\
\mathrm{p}=0.001\end{array}$ & $\begin{array}{l}70(13.1) \\
\mathrm{p}=0.001\end{array}$ & $\begin{array}{l}77(53.1) \\
\mathrm{p}<0.001\end{array}$ & $\begin{array}{c}68(46.9) \\
\mathrm{p}<0.001\end{array}$ \\
\hline
\end{tabular}

\begin{tabular}{|l|l|l|l|}
\hline Table 3. Comparison of Restless Legs syndrome severity between groups ( $=70)$ & p \\
\hline & $\begin{array}{l}\text { RLS severity: } \\
\text { mild-moderate } \\
\text { n (\%) }\end{array}$ & $\begin{array}{l}\text { RLS severity: } \\
\text { severe-very severe } \\
\mathbf{n}(\%)\end{array}$ & \\
\hline Group 1 & $45(75.0)$ & $12(25.0)$ & 0.001 \\
\hline Group 2 & $13(100.0)$ & $0(0.0)$ & $12(20.8)$ \\
\hline Total & $58(79.2)$ & & \\
\hline RLS: Restless Leg syndrome & & \\
\hline
\end{tabular}


In our study; RLS diagnosis was $27.7 \%$ in vitamin D sufficient group which is similar to prevelance studies while RLS diagnosis was $58.2 \%$ in vitamin D deficient group.

Vitamin D levels and RLS association is evaluated in a few studies among non-pregnant population. Atalar recently conducted a study with 152 patients diagnosed with RLS and evaluated outcomes in two different groups: those who were vitamin D deficient (levels less than $20 \mathrm{ng} / \mathrm{mL}$ ) and those who were vitamin $D$ sufficient, as in our study. This study also revealed that vitamin D deficiency is one of the risk factors of RLS development in adults. In vitamin D deficient group; the mean IRLSSG Rating scale score was higher and poor sleep quality was evident (27). Similarly, our vitamin D deficient group's mean IRLSSG Severity scale score was higher with a poorer sleep quality. Another study compared the serum vitamin D levels of RLS patients and matched controls to explore the correlation between the serum vitamin $D$ levels and the disease severity. They have reported a significant inverse correlation between the vitamin $D$ levels and disease severity of RLS in females $(p=0.01)$ (7). Furthermore, results of a study by Oran et al. (8) support an association between vitamin D deficiency and RLS in terms of dopaminergic dysfunction. Wali et al. (9) analyzed patients who had primary RLS and assesed syptoms before and after vitamin $D$ treatment. IRLSSG Severity scores were significantly improved $(p=0.002)$ indicating that vitamin $D$ supplementation improves the severity of RLS symptoms.

RLS may lead to many negative consequences for pregnant woman. In this study, we analyzed sleep quality. Pregnant woman need adequate sleep quality otherwise, sleep disruption may have a negative impact on pregnants' health and fetal development (28-31). An internet based survey indicates that $76 \%$ of women suffers from poor sleep quality across all months of pregnancy (32). RLS is an underdiagnosed sleep disorder which leads to excessive daytime sleepiness, fatigue, low quality of life have been shown in many previous studies $(33,34)$. A cohort study examined sleep disturbances among pregnant woman and RLS was found to be the only factor associated with long-increasing trajectory and sleep disorders (35). RLS affects both sleep onset and duration. Thus far, KIzllırmak et al. (36) found insomnia prevelance $52.2 \%$ in women participating in their study and reported RLS as third common reason for insomnia in pregnancy. In a large cohort, RLS was significantly associated with poor sleep quality, poor daytime function and excessive daytime sleepiness. In our study; $62.2 \%$ of vitamin D deficient group and $14.9 \%$ of vitamin D sufficient group had high PSQI. The positive correlation between PSQI scores and RLS Severity scores of pregnant women was statistically significant. Compared with several studies our findings demonstrate an important role for RLS in poor sleep quality that may adversely affect pregnancy. This correlation was stronger in the vitamin $\mathrm{D}$ deficient group attributed to impaired dopaminergic dysfunction (37).

\section{Study Limitations}

Major strength of this study is that we compared two groups according to RLS prevelance and sleep quality. Exclusion criteria might have provided help to investigate the role of vitamin $D$ in the development of RLS. This study was conducted in a region with a high prevelance of vitamin $D$ deficiency and significant results of our study can also be related to this circumstance. RLS was diagnosed in about nearly half of the total sample, this rate is higher than previous studies. This can be explained with the fact of endemic vitamin D deficiency and that most of the patients were vitamin D deficient. Another limitation of this research is the apparently limited number of control group.

\section{Conclusion}

While various studies have investigated the relationship of vitamin D depletion and RLS prevalance in adults, this relationship was not demonstrated in pregnant women clearly. Vitamin D deficiency was regarded as a contributor to the pathogenesis of RLS during pregnancy in only a review (3). Our study also revealed an inverse association between $25(\mathrm{OH})$ vitamin D plasma concentrations and IRLSSG severity scores in pregnant women. Large randomized controlled trials need to be conducted in order to increase the understanding of the effects of vitamin D supplementation on RLS.

The high prevelance of RLS in pregnant women can significantly impact the health and well-being however, it is often underestimated. RLS is also associated with serious impairment in sleep quality, may worsen the course of pregnancy and interferes with health related quality of life. Obstetric health care providers should be aware of detecting women at risk for RLS, measure serum vitamin $D$ levels during labarotory investigations and diagnosed patients should receive adequate information and reassurance by clinicians.

Acknowledgements: The authors would like to thank the pregnant women participating in this study. On behalf of all authors, the corresponding author states that there is no conflict of interest.

\section{Ethics}

Ethics Committee Approval: We state that this study was approved by an ethics committee (2017/143).

Informed Consent: Informed consent was obtained from all study participants.

Peer-review: Externally peer-reviewed.

\section{Authorship Contributions}

Concept: G.S., Design: G.S., Data Collection or Processing: S.K., Analysis or Interpretation: G.P., B.A.P., Literature Search: G.S., Writing: G.S., D.S.A.

Conflict of Interest: No conflict of interest was declared by the authors.

Financial Disclosure: The authors declared that this study received no financial support.

\section{References}

1. Bjorvatn B, Leissner L, Ulfberg J, Gyring J, Karlsborg M, Regeur L, Skeidsvoll H, Nordhus IH, Pallesen S. Prevalence, severity and risk factors of restless legs syndrome in the general adult population in two Scandinavian countries. Sleep Med 2005;6:307-12. 
2. Hubner A, Krafft A, Gadient S, Werth E, Zimmermann R, Bassetti $\mathrm{CL}$. Characteristics and determinants of restless legs syndrome in pregnancy: a prospective study. Neurology 2013;80:738-42.

3. Gupta R, Dhyani M, Kendzerska T, Pandi-Perumal SR, BaHammam AS, Srivanitchapoom P, Pandey S, Hallett M. Restless legs syndrome and pregnancy: prevalence, possible pathophysiological mechanisms and treatment. Acta Neurol Scand 2016:133:320-9.

4. Minar M, Habanova H, Rusnak I, Planck K, Valkovic P. Prevalence and impact of restless legs syndrome in pregnancy. Neuro Endocrinol Lett 2013;34:366-71.

5. Uglane MT, Westad S, Backe B. Restless legs syndrome in pregnancy is a frequent disorder with a good prognosis. Acta Obstet Gynecol Scand 2011;90:1046-8.

6. Khan M, Mobeireek N, Al-Jahdali Y, Al-Dubyan N, Ahmed A, AlGamedi M Al-Harbi A, Al-Jahdali $\mathrm{H}$. The prevalence of restless leg syndrome among pregnant Saudi women." Avicenna journal of medicine 2018;8:18-23.

7. Balaban H, Yildiz OK, Cil G, Şentürk IA, Erselcan T, Bolayır E, Topaktaş S. Serum 25-hydroxyvitamin D levels in restless legs syndrome patients. Sleep Med 2012;13:953-7.

8. Oran M, Unsal C, Albayrak Y, Tulubas F, Oğuz K, Avcı O, Turgut N, Alp R, Gürel A. Possible association between vitamin D deficiency and restless legs syndrome. Neuropsychiatr Dis Treat 2014;10:953-8.

9. Wali S, Shukr A, Boudal A, Alsaiari A, Krayem A. The effect of vitamin D supplements on the severity of restless legs syndrome. Sleep Breath 2015;19:579-83.

10. Anjum I, Jaffery SS, Fayyaz M, Samoo Z, Anjum S. The role of vitamin D in brain health: a mini literature review. Cureus 201;7:e2960.

11. Palagini L, Gemignani A, Banti S, Manconi M, Mauri M, Riemann D. Chronic sleep loss during pregnancy as a determinant of stress: impact on pregnancy outcome. Sleep Med 2014;15:853-9.

12. Ramirez JO, Cabrera SA, Hidalgo H, Cabrera SG, Linnebank M, Bassetti CL, Kallweit U.Is preeclampsia associated with restless legs syndrome? Sleep Med 2013;14:894-6.

13. Wesstrom J, Skalkidou A, Manconi M, Fulda S, SundstromPoromaa I. Pre-pregnancy restless legs syndrome (Willis-Ekbom Disease) is associated with perinatal depression. J Clin Sleep Med 2014; 10:527-33.

14. Vahdat M, Sariri E, Miri S, Rohani M, Kashanian M, Sabet A, Zamani B. Prevalence and associated features of restless legs syndrome in a population of Iranian women during pregnancy. Int J Gynaecol Obstet 2013;123:46-9.

15. Lee KA, Zaffke ME, Baratte-Beebe K. Restless legs syndrome and sleep disturbance during pregnancy: the role of folate and iron. J Womens Health Gend Based Med 2001;10:335-41.

16. Allen RP, Picchietti D, Hening WA, Trenkwalder C, Walters AS, Montplaisi J, Restless Legs Syndrome Diagnosis and Epidemilogy workshop at the National Institutes of Health; International Restless Legs Syndrome Study Group. Restless legs syndrome: diagnostic criteria, special considerations, and epidemiology. A report from the restless legs syndrome diagnosis and epidemiology workshop at the National Institutes of Health. Sleep Med 2003;4:101-19.

17. International Restless Legs Syndrome Study Group. Revised diagnostic criteria. 2011 [cited 2013 May]. Available from: http:// irlssg.org/diagnostic-criteria

18. Buysse DJ, Reynolds CF, Monk TH, Berman SR, Kupfer DJ. The Pittsburgh Sleep Quality Index: A new instrument for psychiatric practice and research. Psychiatry Research 1989;28:193-213.

19. Garcion E, Wion-Barbot N, Wion D. New clues about vitamin D functions in the nervous system. Trends Endocrinol Metab 2002;13:100-5.
20. Wang JY, Wu JN, Cherng TL, Hoffer BJ, Chen HH, Borlongan CV, Wang Y. Vitamin D3 attenuates 6-hydroxydopamine-induced neurotoxicity in rats. Brain Res 2001;904:67-75

21. Patton SM, Cho YW, Clardy TW, Allen RP, Earley C], Connor JR. Proteomic analysis of the cerebrospinal fluid of patients with restless legs syndrome/Willis-Ekbom disease. Fluids Barriers CNS. Fluids Barriers CNS 2013;10:20

22. Connor JR, Ponnuru P, Wang XS, Patton SM, Allen RP, Earley CJ. Profile of altered brain iron acquisition in restless legs syndrome. Brain 2011;134:959-68.

23. Cervenka S, Pålhagen SE, Comley RA, Panagiotidis G, Cselényi Z, Matthews JC, Lai RY, Halldin C, Farde L. Support for dopaminergic hypoactivity in restless legs syndrome: a PET study on D2-receptor binding. Brain 2006;129:2017-28.

24. Turjanski N, Lees AJ, Brooks DJ. Striatal dopaminergic function in restless legs syndrome: $18 \mathrm{~F}$-dopa and $11 \mathrm{C}$-raclopride PET studies. Neurology 1999;52:932-7.

25. Ruottinen HM, Partinen M, Hublin C, Bergman J, Haaparanta M, Solin O, Rinne JO. An FDOPA PET study in patients with periodic limb movement disorder and restless legs syndrome. Neurology 2000;54:502-4.

26. Picchietti DL, Hensley, JG, Bainbridge JL, Lee KA, Manconi M, McGregor J, Silver RM, Trenkwalder C, Walters AS, International Restless Legs Syndrome Study Group (IRLSSG). Consensus clinical practice guidelines for the diagnosis and treatment of restless legs syndrome/Willis-Ekbom disease during pregnancy and lactation. Sleep medicine reviews 2015;22:64-77.

27. Atalar AÇ. The Relationship Between $25(\mathrm{OH})$ Vitamin D Level and the Severity of Disease and Sleep Quality in Restless Legs Syndrome. Turk J Neurol 2019;25:87-91.

28. Garbazza C, Manconi M. Management strategies for restless legs syndrome/Willis-Ekbom disease during pregnancy. Sleep medicine clinics 2018;13:335-48.

29. Miri S, Rohani M, Vahdat M, Kashanian M, Sariri E, Zamani B, Shahidi GA.. Presenting features of idiopathic versus secondary restless legs syndrome in pregnancy. Iran J Neurol 2014;13:241-4.

30. Sarberg $M$, Josefsson A, Wirehn AB, Svanborg E. Restless legs syndrome during and after pregnancy and its relation to snoring. Acta Obstet Gynecol Scand 2012;91:850-5.

31. Ghanei Gheshlagh R, Lanjavani T, Lazari N, Moslemi B. Comparison of the quality of life in pregnant women with and without restless legs syndrome. J Clin Nurs Midwif 2014;3:54-61.

32. Mindell JA, Cook RA, Nikolovski J. Sleep patterns and sleep disturbances across pregnancy. Sleep medicine 2015;16:483-8.

33. Zucconi M, Manconi M. Sleep and quality of life in restless legs syndrome. In: Verster JC, Pandi-Perumal SR, Streiner D (eds) Sleep and quality of life in clinical medicine. Humana Press, Totowa: NJ; 2008.

34. Meharaban Z, Yahya S, Sadegniiat K. Restless legs syndrome during pregnancy and preterm birth in women referred to health centers of Ardabil. Iranian Red Crescent Medical Journal 2015;17:e24438.

35. Plancoulaine S, Flori S, Bat-Pitault F, Patural H, Lin JS, Franco P. Sleep trajectories among pregnant women and the impact on outcomes: a population-based cohort study. Maternal and child health journal 2017;5:1139-46.

36. Kizılırmak A, Timur S, Kartal B. Insomnia in pregnancy and factors related to insomnia. The Scientific World Journal 2012;2012:197093.

37. Dunietz GL, Lisabeth LD, Shedden K, Shamim-Uzzaman QA, Bullough AS, Chames MC, Bowden MF, O'Brien LM. Restless legs syndrome and sleep-wake disturbances in pregnancy. Journal of Clinical Sleep Medicine 2017;13:863-70. 